\title{
Glacio-meteorological and isotopic studies along the EGIG line, central Greenland
}

\author{
H. Fischer, D. Wagenbach, \\ Institut für Umweltphysik, Universität Heidelberg, D-69120 Heidelberg, Germany
}

M. LATERnSER * AND W. HAEBerLi

Versuchsanstalt für Wasserbau, Hydrologie und Glaziologie, Eidgenössische Technische Hochschule, CH-8092 Zürich, Swizerland

\begin{abstract}
The geographical distribution of firn temperature, annual accumulation rate as well as deuterium and oxygen-18 content in the firn were determined along an east-west transect through central Greenland. This study is based on isotopic and chemical analyses of shallow firn cores at 18 sites along the EGIG line and highprecision firn-temperature measurements in 17 steam-drilled boreholes along the eastern part of the transect. The firn temperatures at $15 \mathrm{~m}$ depth range from $-31.6^{\circ} \mathrm{C}$ at Dome GRIP ( $3230 \mathrm{~m}$ a.s.l.) to $-11.4^{\circ} \mathrm{C}$ at Caecilia Nunatak (eastern ice margin at $1600 \mathrm{~m}$ a.s.l.) and $-18^{\circ} \mathrm{C}$ at $\mathrm{T} 05$ (near the western ice margin at $1900 \mathrm{~m}$ a.s.l.). The temperature/altitude gradient changes from $-0.7^{\circ} \mathrm{C}(100 \mathrm{~m})^{-1}$ in the ice divide region to $-1.1^{\circ} \mathrm{C}(100 \mathrm{~m})^{-1}$ in the eastern part of the dry-snow zone. The temperature/latitude gradient in the central part of the EGIG line is $-0.7^{\circ} \mathrm{C}^{\circ} \mathrm{lat}^{-1}$. The average annual accumulation decreases significantly from the west $\left(\sim 47 \mathrm{~cm} \mathrm{a}^{-1}\right.$ water equivalent at T05) towards the ice divide $\left(20-25 \mathrm{~cm} \mathrm{a}^{-1}\right.$ water equivalent from T99 to T43). Accumulation rates are constantly low east of the ice divide $\left(\sim 23-17 \mathrm{~cm} \mathrm{a}^{-1}\right.$ water equivalent), thus dividing central Greenland into two climatologically different regions. The average $\delta^{18} \mathrm{O}$ and $\delta \mathrm{D}$ values along the whole EGIG line reflect the wellknown temperature-dependence for Greenland very well (e.g. $\partial^{18} \mathrm{O} / \partial T_{\mathrm{m}}=$ $\left.0.69 \%{ }^{\circ} \mathrm{C}^{1}\right)$. Different regression lines for the western and eastern part, however, should be applied. Unlike the mean annual temperature, the isotopic minimum along the EGIG line lies east of the ice divide. This geographical distribution supports the choice of different water-vapour trajectories in central Greenland for the west and for the east. Significant parts of the water precipitated over the western slope are at tributed to cyclonic systems entering Greenland from the west. The deuterium excess shows no significant geographical trend but a uniform seasonal variation at all sites along the EGIG line, suggesting equal contributions from vapour-source areas of the water precipitated over central Greenland.
\end{abstract}

\section{INTRODUCTION}

Over the last three decades, strong efforts have been made to recover deep ice cores from the Greenland ice sheet to provide long-term records of chemical and isotopic signatures over the last climatic cycle. Success of these efforts has made it possible to examine the natural and anthropogenically induced long-term changes of global climate and atmospheric chemistry (Robin, 1983; Finkel and others, 1986; Dansgaard and others, 1993; Fuhrer and others, 1993; Hanson and Saltzman, 1993).

However, the interpretation and intercomparison of isotopic (and chemical) deep ice-core records is not always unambiguous, due to the geographical location of

\footnotetext{
* Presently at Eidgenössisches Institut für Schnee- und Lawinenforschung, Weissfluhjoch, CH-7260 Davos, Switzerland.
}

each individual drill site. Local climatic and overall meteorological conditions influence precipitation processes and transport pathways of chemical species and the water vapour, which are together with source patterns responsible for the isotopic and chemical signature of the snow-pack.

So far, little information has been drawn from the large-scale geographical distribution of isotopic and chemical parameters in Greenland firn and their systematic trends, which are also crucial for the interpretation of the long-term records recovered. For example, Dansgaard (1964) deduced a linear relation between $\delta^{18} \mathrm{O}$ and the condensation temperature at high-altitude sites on the Greenland ice sheet.

Furthermore, only little deuterium excess $(d=\delta \mathrm{D}$ $8 \delta^{18} \mathrm{O}$ ) data for the Greenland ice sheet are available. This hydrological parameter, however, is believed to reflect evaporation conditions in the source area and the advection history of water precipitated over Greenland (Johnsen and others, 1989; Fisher, 1992). Aside from the 
long-term climatic records mentioned above, glaciometeorological parameters (temperature and snow accumulation) may reveal recent climatic changes. In cold firn areas, firn temperature will react with an increase paralleling atmospheric warming (Haeberli, 1990). Also, increased snow deposition in the accumulation areas, due to higher water-vapour content of the advected air masses at higher atmospheric temperatures, may reflect global warming (Morgan and others, 1991).

Against this background investigation of glaciometeorological and isotopic firn parameters it is impor$\tan t$

1. to resolve spatial and temporal changes in climatologically relevant parameters such as temperature and accumulation;

2. to determine the temperature-dependence of accumulation and isotopic content by investigating and thus "simulating" different climatological regimes along the line investigated;

3. to use the geographical distribution of accumulation and isotopic (as well as chemical) parameters to identify sources and transport pathways;

4. to test the representativeness of deep drill sites with respect to the overall geographical and meteorological conditions on the ice sheet.

The reconstruction of the Expédition Glaciologique Internationale au Groenland (EGIG) line by the Institut für Vermessungskunde, Technische Universität Braunschweig, Germany, in 1990-92, allowed us to carry out a glaciological surface study investigating for the first time both glacio-meteorological and isotopic/chemical parameters along a complete west-east transect through central Greenland. Furthermore, the EGIG line, representing the only existing transect previously investigated glaciologically, allows the determination of possible temporal changes in accumulation and firn temperature by direct comparison (Anklin and others, 1994). Seasonal and geographical variations of the parameters investigated in this study are further of fundamental importance as base data for later comparisons.

This paper essentially deals with the temporal variation and geographical distribution of firn temperatures, annual accumulation rates and the isotopic content of the firn along the EGIG line (results of chemical investigations will be published separately elsewhere).

\section{METHODS}

\subsection{Field activities}

This study is based on the activities during two field seasons (in 1990 and 1992) along a traverse through central Greenland. In 1990 further on referred to as EGIG-west), the field party started out at the Greenland Ice Core Project (GRIP) ice-core site (T99) following the ice divide to Crête (T43). From Crête the field party moved westward along the EGIG line to T01 (Fig. 1). Along this route, shallow firn core drillings $(\sim 8 \mathrm{~m})$, pit

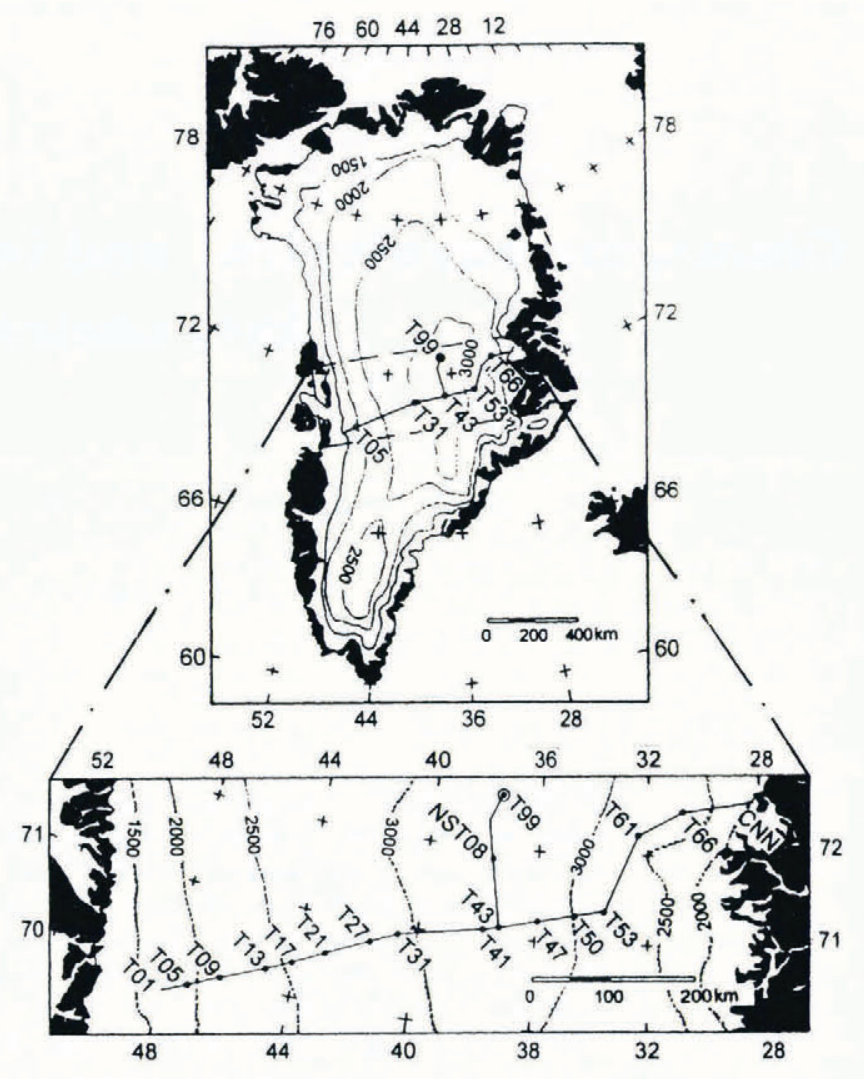

Fig. 1. Map of Greenland showing the drill sites investigated along the EGIG line.

studies and firn-temperature measurements were made at ten sites (Fig. 1). The expedition of the field season 1992 (EGIG-east) again started at GRIP, moved to Crête and then followed the eastern part of the EGIG line to Caecilia Nunatak (CNN), from where it returned the same year. During this second season, shallow firn cores $(\sim 8 \mathrm{~m})$ were drilled and snow pits excavated at eight sites. In addition, high-precision firn-temperature profiles were taken at 17 sites down to a depth of $15 \mathrm{~m}$ using the VAW/ETH-Zürich steam-drilling equipment (Laternser, 1994).

The two field seasons differed significantly in the technique of temperature measurement and sampling procedure, hence for data comparison special care was taken to eliminate systematic effects affecting the temperature and the isotopic and chemical (to be published) content of the samples. For direct comparison between the two seasons, firn cores were drilled at sites T99 and T43 both in 1990 and 1992.

\subsection{Temperature measurements}

For the temperature measurements in 1990, thermistors (Unicurve, $1000 \Omega$ ) with an overall accuracy better than $\pm 0.3^{\circ} \mathrm{C}$ have been used. Due to technical drilling problems and time constraints of the traverse schedule, cores could not be drilled down to the planned depth of $10 \mathrm{~m}$ at all sites. Therefore, all temperature measurements were consistently made at $5 \mathrm{~m}$ depth, where the seasonal temperature oscillation still systematically affects the observed value.

In 1992, however, firn temperatures were measured in steam-drilled boreholes with previously calibrated Fenwal 
thermistors at depths of $3.0,5.0,7.0,9.0,10.0,11.0,12.0$, $13.0,14.0$ and $15.0 \mathrm{~m}$. This $15 \mathrm{~m}$ firn temperature, $T_{15 \mathrm{~m}}$, is closely related to the mean annual firn temperature, $T_{\mathrm{m}}$, which itself is a proxy parameter for the mean annual surface-air temperature, as long as no significant surface meltwater refreezing causes release of latent heat. The boreholes for the temperature measurements were drilled on the way from Dome GRIP to Caecilia Nunatak. Immediately after drilling, they were stabilized at the surface by insertion of a $1 \mathrm{~m}$ long plastic pipe with a removable lid and left open while the traverse continued. Temperatures were finally measured on the return. The time lag between drilling and measurement was several weeks for most of the drill sites which allowed for complete dissipation of the thermal disturbance caused by the steam drilling. Only for sites near the ice margin, the expedition schedule was too tight for complete adjustment. For these sites, extrapolation formulas were applied to gain an "undisturbed" temperature value. In most cases the accuracy was better than $\pm 0.1^{\circ} \mathrm{C}$, often even better than $0.05^{\circ} \mathrm{C}$ (for more details concerning the drilling, measuring and correction techniques for the temperature values along EGIG-east, see Laternser (1994)). To eliminate the seasonal influence on the 1990 data, the temperature offset $\Delta T=T(5 \mathrm{~m}, t)-T_{15 \mathrm{~m}}$ between the temperature $T(5 \mathrm{~m}, t)$ (measured at $5 \mathrm{~m}$ depth and on the date of measurement $t)$ and $T_{15 \mathrm{~m}}$ were calculated.

The time- and depth-dependent temperature profile in the firn may be approximated by Carslaw and Jaeger, 1959)

$$
T(z, t)=T_{15 \mathrm{~m}}+T_{\mathrm{a}} \mathrm{e}^{-k z} \cos (\omega t-k z+\epsilon)
$$

where $T_{\mathrm{a}}$ is the annual temperature amplitude, $z$ is the measured depth, $\omega$ is the frequency of the annual temperature variation $k=\sqrt{w / 2 \kappa}$ with $\kappa$ the firn diffussivity and $\epsilon$ is the phase shift of this oscillation relative to the calendar date $t$. Using the measured temperature profiles of 1992, the parameters $T_{\mathrm{a}}, \epsilon$ and a mean diffusivity $\kappa$ could be numerically fitted (see Fig. 2) for each site. $T_{\mathrm{a}}$ and $\epsilon$ at site T99 were shown to be in good agreement with values from the automated weather station at GRIP (Gundestrup, 1993), and $\kappa$ with values for firn diffusivities given by Lliboutry (1964 65). To calculate $\Delta T$ for the sites of EGIG-west, climatologically comparable sites (equal altitude, similar latitude, and thus similar temperature amplitude and comparable firn stratigraphy) of the eastern part were assigned to the western sites. The temperature offsets $\Delta T$ for the eastern sites were calculated using Equation (1) at the measuring date of 1990 and then subtracted from the $5 \mathrm{~m}$ firn temperature value of the corresponding western sites to gain an undisturbed $15 \mathrm{~m}$ temperature value. The error introduced is difficult to quantify, but the variation of $\Delta T$ between different sites is primarily dependent on $t$ and less so on the fitted parameters $T_{\mathrm{a}}, \epsilon$ and $\kappa$, so the overall accuracy of $T_{15 \mathrm{~m}}$ along EGIG-west may be estimated to be better than $\pm 0.5^{\circ} \mathrm{C}$.

The corrected $5 \mathrm{~m}$ firn temperatures are listed in Table 1 together with the $15 \mathrm{~m}$ firn temperatures measured at the firn-core drill sites along EGIG-east (for a complete listing of the firn temperature measure-

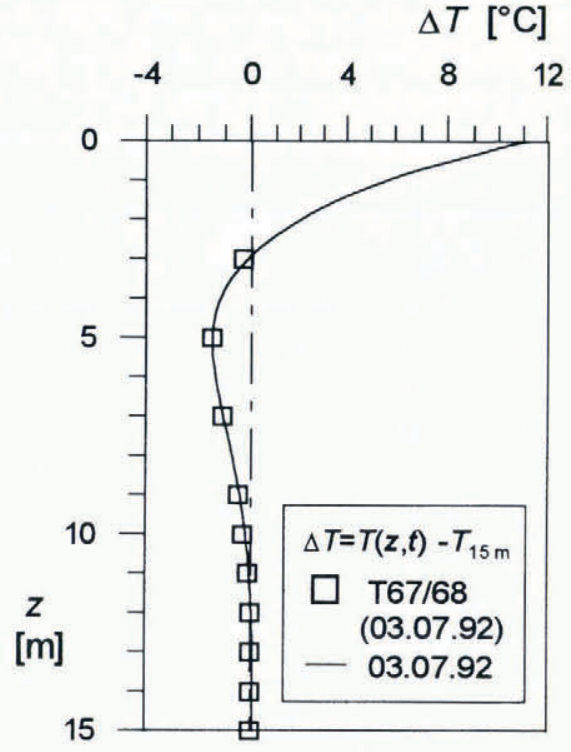

\begin{abstract}
Fig. 2. Firn-temperature profile at site T53. Plotted are the measured (rectangles) and fitted (solid line) values for the deviation $\Delta T$ from the $15 \mathrm{~m}$ firn temperature $T_{15 \mathrm{~m}}$ dependent on the measured depth $z$.
\end{abstract}

ments made in 1992, see Laternser (1994)). The $15 \mathrm{~m}$ temperatures obtained for EGIG-west certainly do not show the very high accuracy of the temperature measurements in the eastern part. Therefore, they are not used to resolve temporal changes in the firn temperature, which are of small magnitude. For the determination of spatial variations in the firn temperature, however, the accuracy of the corrected values is sufficient.

\subsection{Snow-accumulation rates and snow characteristics}

For every drill site, water-equivalent depth scales were obtained by using the corresponding average density values of the single core sections and snow-pit samples measured. At sites T05 and T41 no snow pits were excavated, so these density profiles lack the first $1.5 \mathrm{~m}$. The gap was filled by using the density data of the adjacent sites T09 and T43, respectively. Because this correction only affects the top $0.5 \mathrm{~m}$ water equivalent, and the adjacent sites show very close climatological conditions, the error introduced is assumed to be very small.

Determination of annual accumulation rates in this study was done by counting annual layers of seasonally varying tracers in the firn. For the cores drilled in 1992, $\delta^{18} \mathrm{O}$ profiles together with profiles of major ion concentrations) were measured at high resolution $(\sim 8$ samples year ${ }^{1}$ ) to resolve seasonal variations (Fig. 3), whereas in 1990 the seasonally varying $\mathrm{H}_{2} \mathrm{O}_{2}$ concentration had already been determined in the field in collaboration with the University of Bern Anklin and others, 1994) using a fluorimetric method after Sigg (1990) that proved to be a reliable tool for in-situ accumulation determination. In this study, the summer maxima of the profiles were used to identify single years. In addition, to distinguish summer and winter accumulation, the $\delta^{18} \mathrm{O}-\left(\mathrm{H}_{2} \mathrm{O}_{2}\right)$ profiles were divided into 
Table 1. Climatological and isotopic parameters determined at the sites along the EGIG line: $15 \mathrm{~m}$ firn temperatures together with estimated accuracy in ${ }^{\circ} \mathrm{C}$, average annual accumulation rate in $\mathrm{cm} a^{-1}$ water equivalent, mean summer and winter accumulation in $\mathrm{cm} \mathrm{a}^{-1}$ water equivalent, average annual water-weighted mean of $\delta D$ and the deuterium excess $d$ in $\%$ together with slandard deviations and the number of years $n$ covered by the firn cores

\begin{tabular}{|c|c|c|c|c|c|c|c|}
\hline Site & $T_{15 \mathrm{~m}}$ & $a c c$ & $a c c_{\text {summer }}$ & $a c c_{\text {winter }}$ & $\delta D$ & $d$ & $n$ \\
\hline T05 & $-18.0 \pm 0.5$ & $46.0 \pm 10.2$ & $16.1 \pm 8.6$ & $24.4 \pm 6.1$ & $-201.1 \pm 10.0$ & $11.9 \pm 1.4$ & 8 \\
\hline Т09 & $-20.0 \pm 0.5$ & $40.5 \pm 8.9$ & $15.8 \pm 7.7$ & $24.3 \pm 4.8$ & $-202.4 \pm 16.2$ & $12.9 \pm 1.4$ & 9 \\
\hline T13 & $-22.6 \pm 0.5$ & $45.9 \pm 9.1$ & $20.0 \pm 4.1$ & $25.9 \pm 4.8$ & $-214.3 \pm 11.2$ & $13.3 \pm 1.8$ & 8 \\
\hline T17 & $-23.8 \pm 0.5$ & $44.4 \pm 7.9$ & $19.1 \pm 4.9$ & $24.4 \pm 6.2$ & $-224.1 \pm 7.4$ & $13.0 \pm 1.9$ & 9 \\
\hline T21 & $-24.8 \pm 0.5$ & $43.9 \pm 8.8$ & $19.0 \pm 5.0$ & $23.9 \pm 4.9$ & $-230.2 \pm 12.2$ & $12.4 \pm 1.3$ & 9 \\
\hline $\mathrm{T} 27$ & $-26.6 \pm 0.5$ & $38.5 \pm 6.5$ & $15.7 \pm 5.1$ & $22.8 \pm 2.7$ & $-237.2 \pm 10.8$ & $13.1 \pm 2.2$ & 9 \\
\hline T31 & $-27.5 \pm 0.5$ & $34.4 \pm 6.2$ & $15.0 \pm 3.7$ & $20.4 \pm 3.6$ & $-245.6 \pm 10.6$ & $13.1 \pm 2.3$ & 10 \\
\hline T41 & $-29.5 \pm 0.5$ & $25.0 \pm 3.5$ & $9.9 \pm 2.5$ & $14.5 \pm 2.7$ & $-253.1 \pm 5.6$ & $12.6 \pm 0.8$ & 12 \\
\hline Т43 ('90) & - & $22.9 \pm 3.9$ & $10.2 \pm 2.7$ & $11.9 \pm 2.2$ & $-254.3 \pm 14.0$ & $13.3 \pm 2.2$ & 14 \\
\hline T99 ('90) & - & $20.0 \pm 3.5$ & - & - & $-269.1 \pm 11.3$ & $13.4 \pm 2.4$ & 21 \\
\hline T99 ('92) & $-31.62 \pm 0.03$ & $18.8 \pm 4.9$ & $8.0 \pm 3.5$ & $11.1 \pm 3.9$ & $-266.3 \pm 7.7$ & $13.6 \pm 1.4$ & 8 \\
\hline NST08 & $-30.95 \pm 0.03$ & $22.9 \pm 2.8$ & $7.9 \pm 1.6$ & $15.2 \pm 3.2$ & $-265.1 \pm 10.8$ & $10.7 \pm 0.5$ & 5 \\
\hline T43 ('92) & $-30.07 \pm 0.03$ & $25.4 \pm 4.4$ & $11.0 \pm 3.3$ & $14.1 \pm 3.8$ & $-250.9 \pm 9.9$ & $13.3 \pm 0.8$ & 8 \\
\hline T47 & $-29.92 \pm 0.03$ & $22.1 \pm 3.6$ & $11.3 \pm 1.5$ & $10.7 \pm 2.1$ & $-263.3 \pm 9.3$ & $12.2 \pm 0.9$ & 8 \\
\hline T50 & $-28.96 \pm 0.03$ & $22.7 \pm 0.9$ & - & - & $-254.2 \pm 12.8$ & $10.3 \pm 1.5$ & 2 \\
\hline T53 & $-27.97 \pm 0.03$ & $23.2 \pm 4.6$ & $12.1 \pm 2.5$ & $11.0 \pm 2.5$ & $-255.0 \pm 9.0$ & $11.0 \pm 0.9$ & 9 \\
\hline T61 & $-28.82 \pm 0.03$ & $18.7 \pm 5.2$ & $9.0 \pm 3.3$ & $10.1 \pm 3.5$ & $-254.2 \pm 10.0$ & $12.8 \pm 1.2$ & 8 \\
\hline T66 & $-25.66 \pm 0.05$ & $16.8 \pm 4.1$ & - & - & $-239.7 \pm 13.6$ & $10.0 \pm 1.0$ & 6 \\
\hline
\end{tabular}

summer and winter half-years, with their limits being defined by the mean value between adjacent summer maxima and winter minima (Fig. 3). This method, however, only works if the profiles of the tracers which are regarded as temperature-proxy parameters follow closely the sinusoidal annual temperature variation. This con- dition seems to be sufficiently obeyed by all firn cores; however, the relative position of the limits between maxima and minima varies. To interpret the seasonal precipitation pattern, therefore, only averaged summer and winter accumulation values are considered.

In addition to snow-pit sampling at each drill site,
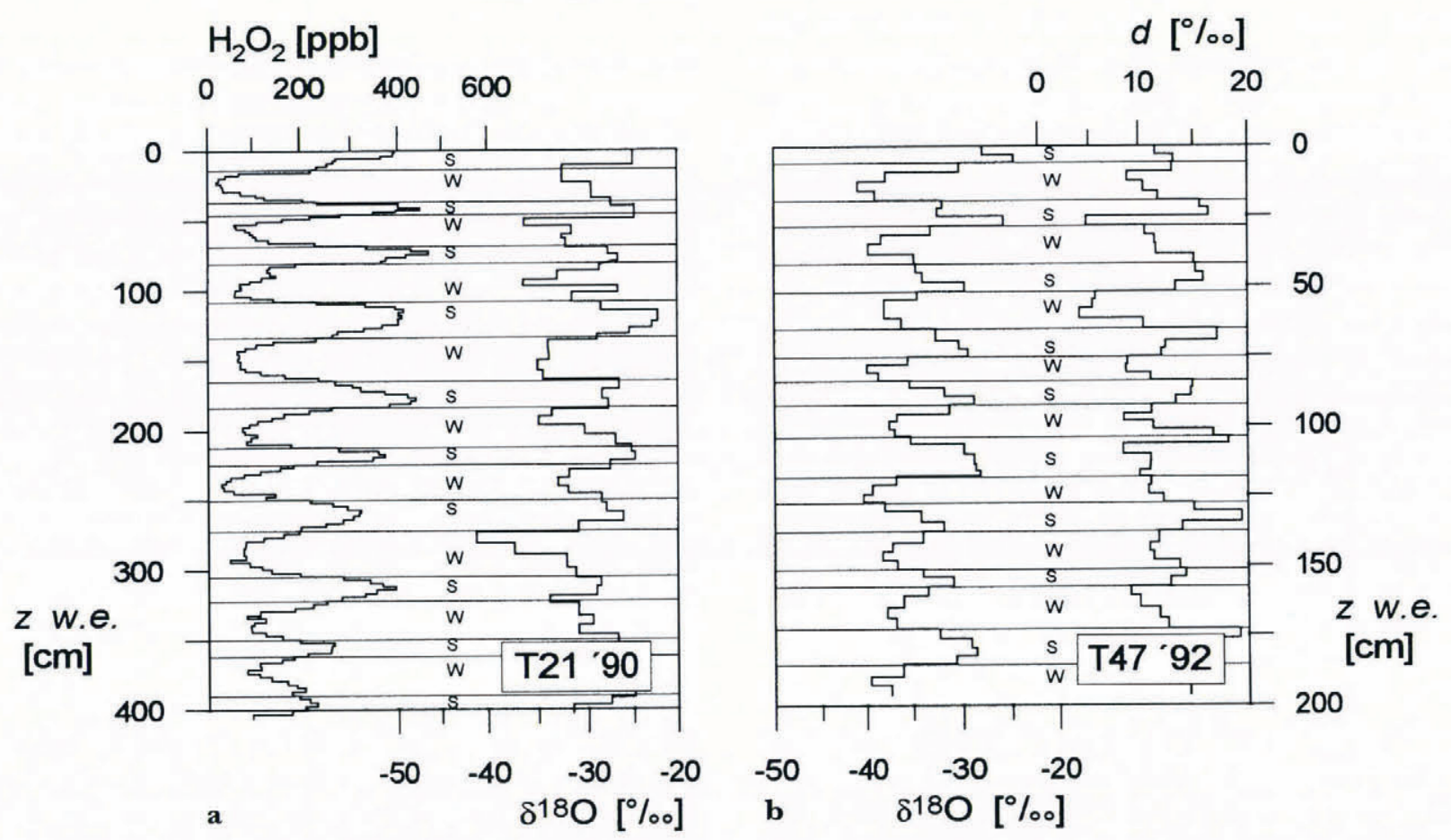

Fig. 3. Firn-core profiles of seasonally varying tracers: (a) $\mathrm{H}_{2} \mathrm{O}_{2}$ and the accompanying $\delta^{18} \mathrm{O}$ profile at site $\mathrm{T} 21$ of EGIG-west; (b) $\delta^{1 B} O$ and d profile at site T47 of EGIG-east. Apart from the consecutive summer maxima $(S)$ and winter minima $(W)$, the limits between single half-years (grid lines) are plotted. 
further detailed pit studies were done at 21 places along EGIG-east, where the stratigraphy was observed and both temperature and density profiles were measured. Within the dry-snow and upper percolation zones, the surface layer was generally built up of small, rounded grains, possibly topped by precipitation or decomposing and fragmented precipitation particles from recent snowfalls. This layer containing last winter's accumulation on average reached a depth of about $60-80 \mathrm{~cm}$. Below that the crystals often showed a sharp change to facetted or even cup-shaped forms of considerably larger size marking last year's summer horizon. This depth was usually characterized by a significant "dent" in the density profile. Further down, the crystals generally remained facetted, sometimes showing mixed forms with rounded grains again. Depending on the individual site and the depth of the corresponding pit, a second summer horizon, usually less distinct than the previous one, could be found at depths of around $120-160 \mathrm{~cm}$. Fine "ice skins" caused by either melt or wind polish were encountered throughout all profiles. Closer to the ice margin (lower percolation and wet-snow zone), the thickness of the layers grew considerably and the occurrence of refrozen firn and actual wet grains became more frequent (for a detailed presentation of all snowcover profiles along EGIG-east, see Laternser (1994)).

\section{4. $\delta^{18} \mathrm{O}, \delta \mathrm{D}$ and deuterium excess}

All samples were measured for $\delta^{18} \mathrm{O}$ and $\delta \mathrm{D}$ by mass spectrometry at the Institut für Umweltphysik, Heidelberg. Two cores were isotopically analysed at the GSF Forschungszentrum für Umwelt und Gesundheit, Institut für Hydrologie, Neuherberg. The current overall accuracy of these measurements is $0.1 \%$ for $\delta^{18} \mathrm{O}$ and $2.0 \%$ for $\delta \mathrm{D}$, leading to an accuracy for the deuterium excess $d=\delta \mathrm{D}-8 \delta^{18} \mathrm{O}$ of $2.2 \%$ for every single sample.

In 1992, the firn cores and snow-pit samples were brought back frozen to Heidelberg using the GRIP cooling facilities. For the 1990 field season, however, it was not possible to get this logistic support, so samples could melt during transport from Jacobshavn to Heidelberg. Therefore, special care was taken to preserve seasonal resolution of the isotopic and chemical profiles and to prevent chemical contamination and watervapour exchange with the surrounding air, which alters the isotopic signature of the samples.

To do so, the drilled firn cores were subdivided into seasonal sub-samples in the field according to the $\mathrm{H}_{2} \mathrm{O}_{2}$ profile (4-8 samples year ${ }^{-1}$; see also Figure 3 ), thoroughly decontaminated for later chemical analyses and sealed in polyethylene (PE) bags, which were pre-cleaned with highly purified water. The samples from each site were then put into a larger closed PE bag. Liquid water within this PE bag (as a result of occasionally occurring sample leakages) built up a separate water-vapour atmosphere with identical average isotopic content as the samples themselves, reducing water-vapour exchange with the ambient air significantly. To quantify possible changes in the isotopic content of the melted samples, various laboratory experiments were made, simulating the possible effects of water-vapour exchange and/or loss through the walls and seals of the sample PE bags. These experiments proved that thoroughly sealed samples, packed in the way described above, were (compared to the overall accuracy of the measurement) unaffected in their isotopic content $\left(\Delta \delta^{18} \mathrm{O}< \pm 0.15 \%, \Delta \delta \mathrm{D}< \pm 2.5 \%\right.$ and $\Delta d< \pm 2.1 \%$ ). Only a few of those samples subject to extensive vapour diffusion through intentionally punctured walls or seals of the bag showed significantly lowered deuterium excess values but only slightly altered $\delta^{18} \mathrm{O}$ and $\delta \mathrm{D}$ values. Therefore, all samples subject to obvious leakages and with negative deuterium excess values were excluded from further analysis. The part of affected samples varied between 5 and $20 \%$ for the different drill sites. Using the reduced data set, the average annual water-weighted mean of $\delta^{18} \mathrm{O}, \delta \mathrm{D}$ and $d$ for sites T99 and T43 could be calculated and statistically tested against the unaffected values for the drilling in 1992 at the same sites. For the parallel drillings at sites T99 and T43 both $t$-test and the parameter-free Wilcoxon test showed no significant difference $(p=5 \%)$ for the average of $\delta^{18} \mathrm{O}, \delta \mathrm{D}$ and even for the more sensitive deuterium excess between the two field seasons. The findings of these experiments and tests prove that the reduced data set is reliable.

The $\delta^{18} \mathrm{O}, \delta \mathrm{D}$ and $d$ profiles (see Fig. 3) show variations between each annual cycle, so for further interpretations mean annual cycles were calculated wherever temporal resolution was high enough $>6$ samples year $\left.{ }^{-1}\right)$. To do so, the depth interval between summer maxima and winter minima in Figure 3 were divided into three equidistant sub-intervals, leading to a temporal resolution of 2 months, if an homogeneous accumulation rate throughout the year is assumed. To calculate the average annual cycle, the water-weighted mean for every generated 2 month interval was determined and then averaged over all years covered.

\section{RESULTS AND DISCUSSION}

\subsection{Firn temperature}

\subsubsection{Temporal variations}

While the ablation zone of an ice sheet will react with increased melting on climatic warming, the accumulation zone will mainly show a change in the firn temperature accompanying the atmospheric temperature change (Haeberli, 1990). Hence, the measurement of this parameter allows determination of a possible climatic change on the ice sheet by comparison with previously measured firn temperatures in the area under investigation. The firn temperatures for the western part of the EGIG line (contrary to the $15 \mathrm{~m}$ firn-temperature values along EGIG-cast) do not show the required accuracy for such a comparison, due to the $5 \mathrm{~m}$ firn-temperature correction carried out. Therefore, in Table 2 only the 1992 temperature values for sites T43 and T53 are listed together with values by de Quervain (1969) for the time span 1959 64. Comparisons between these two measurements show no significant temperature change within the error limits (Laternser, 1994). However, temperature profiles measured in deep boreholes in the Greenland ice sheet show distinct heat-flux anomalies caused by strong secular warming followed by slight cooling after about 1950 (Robin, 1983). The similarity of the 1992 and 1959 
Table 2. Comparison of firn temperatures determined by de Quervain (1969) during the time span 1959-64 with the firn lemperatures measured in 1992. The given firn temperatures $T(z, t)$ in ${ }^{\circ} \mathrm{C}$ for 1992 are corrected for the date of measurement and the measured depth in $m$ of the values by de Quervain and others (Laternser, 1994). Also given are the estimated measurement accuracies

\begin{tabular}{ccccc}
\hline Site & Date $_{\mathrm{de}} \mathrm{Q}^{*}$ & Depth $_{\mathrm{de}} \mathrm{Q}$ & $T_{\mathrm{de}} \mathrm{Q}$ & $T(z, t)$ \\
\hline \multirow{2}{*}{$\mathrm{T} 43$} & $06 / 23 / 59$ & $15.4 \pm 0.1$ & $-29.9 \pm 0.13$ & $-30.1 \pm 0.1$ \\
& $06 / 13 / 64$ & $11.2 \pm 0.1$ & $-29.7 \pm 0.13$ & $-30.1 \pm 0.1$ \\
$\mathrm{~T} 53$ & $10.4 \pm 0.1$ & $-27.9 \pm 0.13$ & $-28.1 \pm 0.1$ \\
& $07 / 23 / 59$ & $11.1 \pm 0.1$ & $-28.0 \pm 0.13$ & $-28.0 \pm 0.1$ \\
& $07 / 31 / 59$ & $15.7 \pm 0.1$ & $-28.0 \pm 0.13$ & $-27.9 \pm 0.1$ \\
& $07 / 30 / 59$ & $11.4 \pm 0.1$ & $-27.8 \pm 0.13$ & $-27.9 \pm 0.1$ \\
& $07 / 21 / 60$ & $16.0 \pm 0.1$ & $-28.0 \pm 0.13$ & $-27.9 \pm 0.1$ \\
& $06 / 21 / 60$ & $13.4 \pm 0.1$ & $-27.6 \pm 0.13$ & $-27.9 \pm 0.1$ \\
& $06 / 15 / 64$ & $17.9 \pm 0.1$ & $-27.7 \pm 0.13$ & $-27.9 \pm 0.1$ \\
\hline $06 / 10 / 64$ & & & \\
\hline
\end{tabular}

* de Quervain.

64 values could, therefore, possibly indicate recent rewarming of firn temperatures to the high levels previously reached around 1950. Comparison with later temperature measurements along the EGIG line will clarify whether a long-term warming trend persists.

\subsubsection{Geographical distribution}

The $15 \mathrm{~m}$ firn temperatures along the EGIG line show the expected linear relation between altitude and latitude (Fig. 4). The areas marked A and B in Figure 4 represent sections of approximately equal altitude but

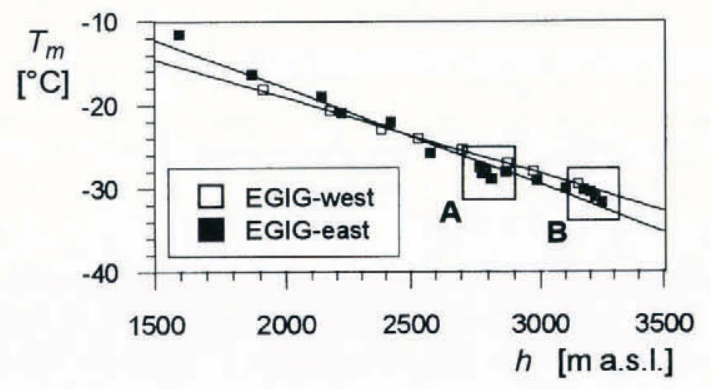

Fig. 4. Temperature altitude dependence for all investigated sites along the EGIG line. Areas $A$ and $B$ indicate regions of approximately equal altitude but different latilude.

different latitude. In addition, the geographical distribution of $T_{15 \mathrm{~m}}$ along the EGIG line is plotted in Figure 5b, showing the temperature minimum is situated directly on the ice divide. Note that in Figure $5 b$ distance to the ice divide parameterizes both altitude and latitude of the drill site.

For the central dry-snow zone of EGIG-east (from site T99 via T43 to T53), the route of the EGIG line allows the decoupling of altitude and latitude effects for the $15 \mathrm{~m}$ firn temperature by means of multiple regression. The corresponding partial temperature gradients are:

$$
\begin{aligned}
& \left(\frac{\partial T_{15 \mathrm{~m}}}{\partial h}\right)_{\substack{\text { central } \\
\text { cast }}}=-(0.72 \pm 0.06)^{\circ} \mathrm{C}(100 \mathrm{~m})^{-1} \\
& \left(\frac{\partial T_{15 \mathrm{~m}}}{\partial \lambda}\right)_{\substack{\text { central } \\
\text { cast }}}=-(0.71 \pm 0.16)^{\circ} \mathrm{C}^{\circ} \mathrm{lat}^{-1}, \quad r^{2}=0.98
\end{aligned}
$$

( $h$ is the altitude and $\lambda$ is the latitude of the drill site). Along the eastern slope from site T65 to T69, where the latitude of the traverse route remained almost constant, the $15 \mathrm{~m}$ firn temperature-altitude gradient is

$$
\left(\frac{\partial T_{15 \mathrm{~m}}}{\partial h}\right)_{\text {east }}=-(1.09 \pm 0.05)^{\circ} \mathrm{C}(100 \mathrm{~m})^{-1}, \quad r^{2}=0.99
$$

and even higher in the lower percolation and wet-snow zone $\left(-1.4^{\circ} \mathrm{C}(100 \mathrm{~m})^{-1}\right.$; Laternser, 1994). These differences are attributed to increased latent-heat transport through the firn due to higher firn densities and occasionally occurring meltwater percolation for a detailed description of the temperature and stratigraphical findings along EGIG-east, see Laternser (1994)).

Due to the high intercorrelation of altitude and latitude of the drill sites along the EGIG-west traverse, no unambiguous decoupling of the two parameters on the measured firn temperatures (from site T05 to T41) by multiple regression is possible. Linear regression leads to an overall (including latitude effects) $15 \mathrm{~m}$ firn temperature-altitude gradient of $-0.94^{\circ} \mathrm{C}(100 \mathrm{~m})^{-1}\left(r^{2}=0.99\right)$. If the $15 \mathrm{~m}$ firn temperature-latitude gradient for the central-eastern part in Equation (3) is applied, one obtains a latitude-corrected $15 \mathrm{~m}$ firn temperaturealtitude gradient of $-0.87^{\circ} \mathrm{C}(100 \mathrm{~m})^{-1} \quad\left(r^{2}=0.99\right)$ for the western part of the EGIG line. This temperature latitude gradient in the west is higher than in the centraleastern dry-snow zone (Equation (2)) but lower than on the eastern slope from site T65 to T69 (Equation (4)). The differences result from averaging of different snow zones when applying linear regression on the whole western EGIG line. A more detailed investigation of the 


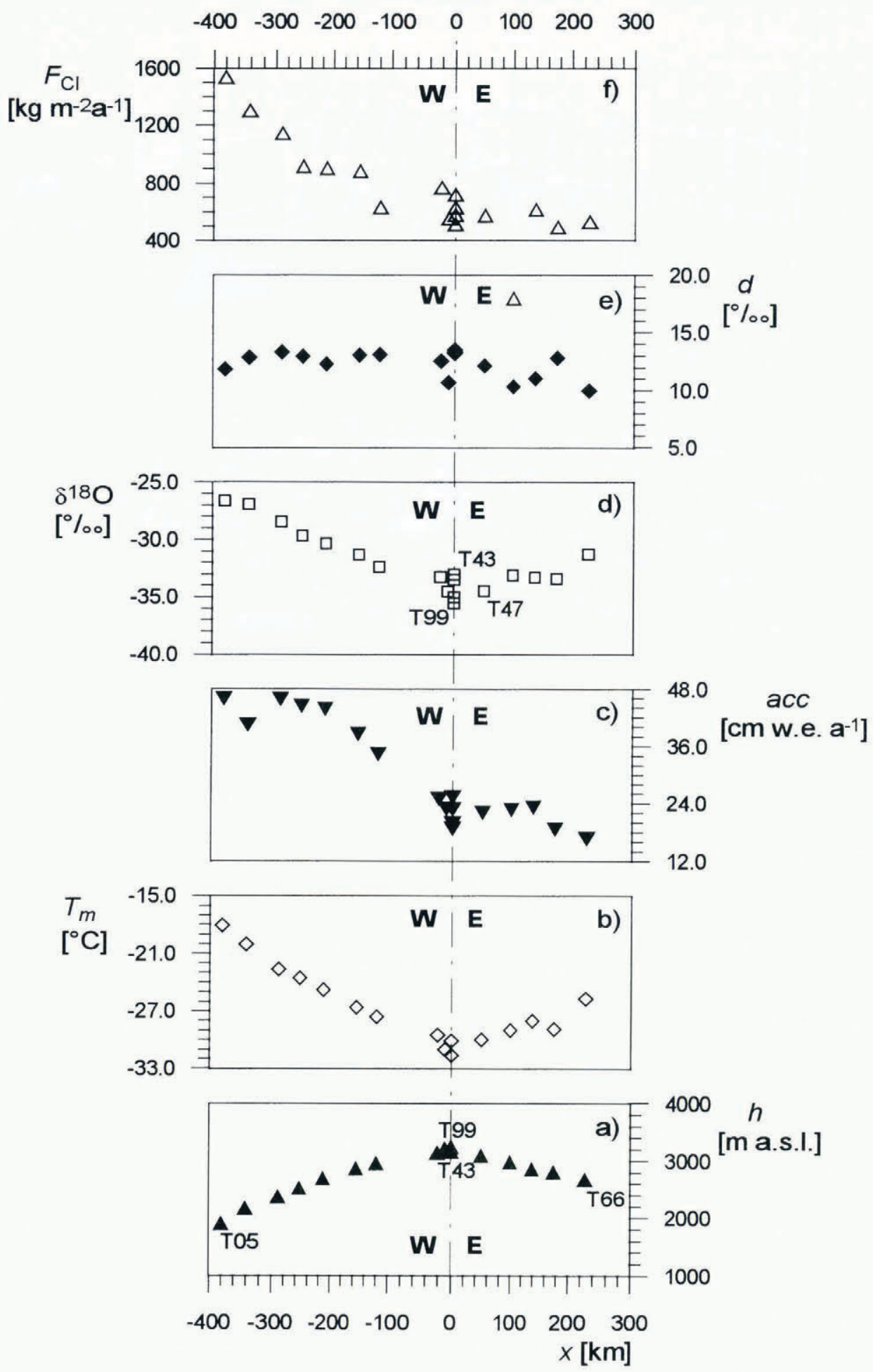

Fig. 5. Geographical distributions of various parameters investigated along the EGIG line dependent on the distance from the ice divide $x:$ (a) altitude above sea level $h ;$ (b) $1.5 \mathrm{~m}$ firn temperature $T_{15 \mathrm{~m}}$; (c) average annual accumulation rate acc; (d) average annual water-weighted mean of $\delta^{18} \mathrm{O} ;(e)$ average annual water-weighted mean of the dueterium excess $d ;(f)$ average annual chloride deposition flux $F_{\mathrm{Cl}}$.

geographical temperature distribution along EGIG-west, however, cannot be attempted because of the substantial $5 \mathrm{~m}$ firn-temperature correction described in section 2.2.

\subsection{Accumulation}

\subsubsection{Temporal varialions}

By stratigraphical dating of the ice cores (see section 2.3), we were able to derive the annual accumulation deposited in every firn core. In Figure 6, accumulation is plotted for the common time span covered by all cores (1989 93). Apart from the geographical trend described in section 3.2.3), Figure 6 shows distinct temporal features (valleys and ridges) along the whole EGIG line, revealing that the annual accumulation variability is a large-scale phenomenon. However, an overall temporal trend cannot be identified. This is also supported by Anklin and others (1994), who, by means of comparison with earlier 


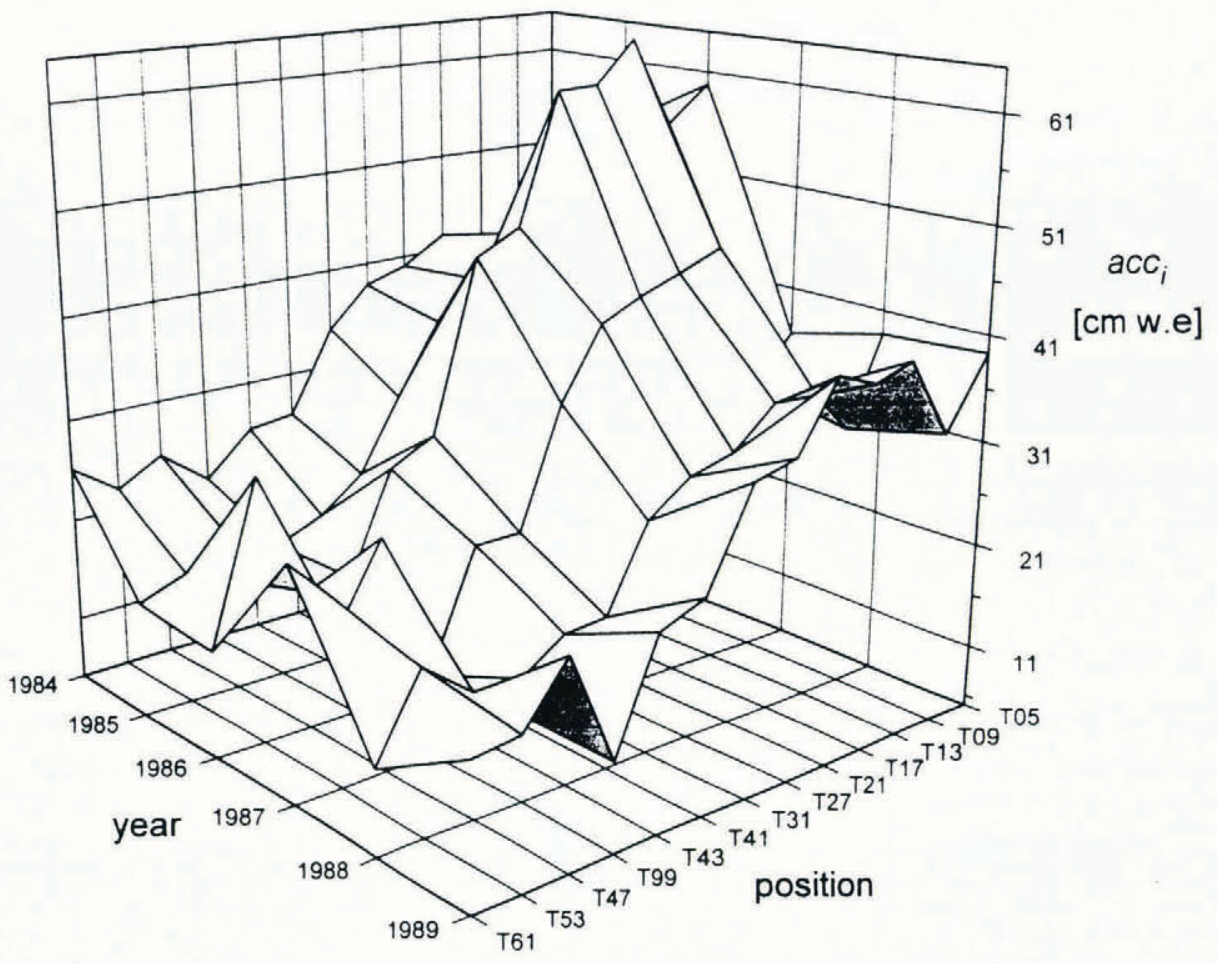

Fig. 6. Spatial and temporal variation of the annual accumulations for the common time span covered by all firn cores.

measurements along the western EGIG line, found no significant temporal change in the precipitation pattern over West Greenland during the last 30 years. For the eastern part, only a few previous accumulation measurements are available. These are listed in Table 3 together with the values determined in this study. The methods used by the authors listed in Table 3 to determine the average annual accumulation rate significantly differ from the $\delta^{18} \mathrm{O}$ method used in this study (see section 2.2). Merlivat and others (1973) gave tritium-based values indicating mean annual accumulations for the time span 1959-68. de Quervain (1969) used a combination of snow-stake measurements and density together with hardness profiles at sites T47, T53 and T61, and Boutron (1979) used snow stakes at site T46. The latter site is close to site T47 and is therefore used for comparison. The geodetic study by Seckel (1977) gave mean annual snow thicknesses for the time span 1956-68. For comparison with our own data, these have to be converted into waterequivalent values. Since no density measurements were made by Seckel, we use our density profiles from 1992. This procedure seems to be justified, since the mean annual temperature, and hence the snow texture at the drill sites, has not changed significantly since $1959-68$ (see section 3.1.1). The same procedure was used by Anklin and others (1994) for EGIG-west, resulting in good agreement of the converted values with the data determined in their study.

Comparison of the values for sites T47 and T53 shows no significant difference between the authors except the values of Seckel, which are $\sim 20 \%$ lower. The values of Seckel for these sites, however, are also inconsistently low compared to his accumulation rates for the adjacent sites in the west (T41 and T43). For sites T61 and T66, the values given by Merlivat and others (1973) agree very well with our recent data. However, de Quervain (1969) gave an accumulation rate for site $\mathrm{T} 61$ which is significantly higher.

Summarizing this comparison for the eastern part of the EGIG line, we conclude that the average annual accumulation rate most likely has not changed during the last 30 years. However, the sparse data available for this region is not free from ambiguities, and therefore does not allow a final statement. The data determined in this study are therefore of great importance as a reference for future measurements along the EGIG line.

Table 3. Comparison of average annual accumulation rates by Boutron (1979), Merlivat and others (1973), Seckel (1977) and de Quervain (1969) with the values determined in this study together with their slandard deviations. In addition to the accumulation rales in $\mathrm{cm} \mathrm{a}^{-1}$ water equivalent, the corresponding time spans are listed 


\subsubsection{Geographical distribution}

The geographical distribution of the mean annual accumulation rate is plotted in Figure 5c. A first inspection allows one to subdivide the area under investigation into three different regions:

1. A high-accumulation plateau $\left(\sim 45 \mathrm{~cm} \mathrm{a}^{-1}\right.$ water equivalent) from site T05 to site T17. At site T09, accumulation is slightly reduced compared to sites T05 and T13, probably due to surface undulations (Hempel, 1994) that occur at this site, which locally may result in a partial loss of the annual accumulation by wind drift.

2. Steadily decreasing accumulation rates from site $\mathrm{T} 21$ ( $\sim 43 \mathrm{~cm} \mathrm{a}^{-1}$ water equivalent) to site $\mathrm{T} 43\left(\sim 25 \mathrm{~cm} \mathrm{a}^{-1}\right.$ water equivalent) and further on to site T99 ( $\sim 20 \mathrm{~cm} \mathrm{a}^{-1}$ water equivalent).

3. Constant accumulation rates in the eastern part of the EGIG line (sites T47-T66, $\sim 23-17 \mathrm{~cm} \mathrm{a}^{-1}$ water equivalent).

This overall geographical distribution along the EGIG line supports the picture of a main water-vapour trajectory along the western slope of central Greenland from west to east, resulting in decreasing accumulation rates due to gradual water-vapour loss by cooling during ascent and a precipitation shadowing lee sides of the ice divide in the east. Air masses entering Greenland from the east, however, seem to be substantially reduced in their water-vapour content, because of heavy precipitation during their ascent over the steep coastal range. Thus, they are unable to produce high accumulation rates on top of the ice sheet. Comparison with the accumulation map for Greenland compiled by Ohmura and Reeh (1991) (based on data from various expeditions and values provided by meteorological stations along the Greenland coast) shows good agreement in the central part of the ice sheet and slightly lower values along the western and eastern slope in this study which, however, are still within the standard deviation.

In addition to the mean annual accumulation, the corresponding values of the summer and winter halfyears defined by the $\mathrm{H}_{2} \mathrm{O}_{2}$ and $\delta^{18} \mathrm{O}$ profiles (see section 2.3 are listed in Table 1 . In the west, accumulation during the winter half-year is $20-40 \%$ higher than in the summer half-year. Although one cannot define precisely the annual accumulation maximum, this rough seasonal distribution does not support the view of Ohmura and Reeh, who proposed a precipitation maximum on the western slope in summer. However, their conclusion is based on the precipitation measurements at meteorological stations at sea level. Therefore, this would indicate a significant difference between coastal and inland sites with respect to their seasonal precipitation patterns.

Further inland, the excess accumulation decreases to the ice divide. In the eastern part, precipitation during the summer and the winter half-years is of comparable magnitude. This temporal and spatial distribution supports cyclonic influence, which is greatly enhanced in the winter half-year, as being responsible for the main parts of the annual accumulation. Mean weather charts compiled by Liljequist (1970) indicate that these cyclones enter Greenland through Davis Strait, causing substantial snowfalls on the western slope. Precipitation terminates when these systems pass the ice divide.

This cyclonic influence also explains the geographical and seasonal distribution of the chloride deposition. Marine trace elements in the firn, such as chloride and sodium, originate from sea-salt dispersion over the ocean and are transported to the central Greenland ice sheet via the free troposphere (Steffensen, 1988). The chloride input into the free troposphere is greatly dependent on the storm, hence cyclonic, activity in the source region, the chloride content of the lower troposphere in the vicinity of the Greenland coast, and on local sea-ice conditions.

In Figure 5f, the average annual chloride-deposition flux $F_{\mathrm{Cl}}=\frac{1}{n} \sum_{i=1}^{n} \mathrm{Cl}^{i} \cdot a c c^{i}$ is plotted $\mathrm{Cl}^{i}$ is the annual water-weighted chloride concentration, $a c c^{i}$ is the annual accumulation of year $i$ and $n$ is the number of years covered by the firn core). Here, $F_{\mathrm{Cl}}$ shows a rapid decrease from the west coast to the ice divide, which significantly exceeds a decrease solely produced by the decline of the accumulation rate. Towards the eastern coast, however, $F_{\mathrm{Cl}}$ remains constant. This indicates that the main cyclonic influence driving marine-aerosol species to the ice sheet enters Greenland from the west.

The seasonal variation of the chloride concentration (Fig. 9c) shows a maximum at all EGIG sites during spring, which is attributed to the enhanced cyclonic activity over the Atlantic Ocean during this season. Similar findings also hold for other drill sites throughout inland Greenland (Mayewski and others, 1987; Davidson and others, 1989; Beer and others, 1991). Aerosol concentrations at coastal sites (Heidam, 1981), however, show a chloride maximum in summer caused by sea-salt uptake from the local ocean surface, probably being suppressed during early winter/spring due to local sea-ice coverage. This difference in the seasonal chloridedeposition patterns of coastal and inland sites leads to the conclusion that the lower troposphere, causing the chloride concentrations at sea-level altitude, does not affect efficiently the snow chemistry on top of the Greenland ice sheet.

To predict changes in annual accumulation rates in Greenland for altered climatic conditions, the relationship between accumulation and temperature is required. The average accumulation rate, as well as the isotopic content of the firn, is greatly dependent on the condensation temperature $T_{c}$. This temperature, however, is not necessarily equal to the mean annual surface temperature, due to the often prevailing temperature inversion above the ice sheet. Unfortunately, no adequate data for the inversion strength over the Greenland ice sheet are available. For Antarctica, Phillpot and Zillman (1970) stated a linear relationship between $T_{\mathrm{c}}$ and $T_{\mathrm{m}}$. Furthermore, most of the accumulation over Greenland is caused by cyclonic systems, which destroy any existing inversion layer. These single precipitation events therefore greatly influence the average and the geographical distribution of the condensation temperature. Precipitation-weighted temperatures therefore should be used (Fisher, 1990). Due to the lack of detailed climatological temperatures along the EGIG line, the firn-temperature data determined in this study constitute the only representative recent temperature data available. There- 
fore, we prefer an empirical approach, based on the climatological division of the area investigated described above, which describes the relationship between the $15 \mathrm{~m}$ firn temperatures and the average annual accumulation rates.

The westernmost part of the EGIG line (sites T05T17) in Figure 7 shows decreasing $15 \mathrm{~m}$ firn temperatures from $-18^{\circ}$ to $-24^{\circ} \mathrm{C}$ but no significant spatial change in the accumulation rate. The central western slope (sites T21-T43 and further on to site T99), however, shows a linear decrease of the accumulation rate, which accompanies a decline of $T_{15 \mathrm{~m}}$ from $-24^{\circ}$ to $-32^{\circ} \mathrm{C}$. Linear regression for this section yields

$$
\begin{aligned}
& a c c=(3.66 \pm 0.20) T_{15 \mathrm{~m}}+(134.81 \pm 5.71) \\
&\left(\mathrm{cm} \mathrm{a}^{-1} \text { water equivalent }\right), \quad r^{2}=0.98 .
\end{aligned}
$$

Since precipitation essentially depends on the watervapour pressure at saturation, being mainly a function of temperature, this geographical temperature relationship of the accumulation rate can also be mapped on to temporal temperature changes, provided that the circulation pattern over the Greenland ice sheet and, hence, the precipitation history of the advected air masses have not changed. Thus, we can conclude that the annual accumulation rate in this area linearly reacts to occurring temperature variations. Note that Equation (6) only holds west of the ice divide, while in the eastern part accumulation is constantly low even at the easternmost site T66, which is close to the coast. Here, the existence of the geographical barrier constituted by the coastal range and possible radiative cooling by the prevailing sea-ice coverage results in significant reduction of the watervapour content before air masses advected from the east are able to penetrate on to the ice sheet.

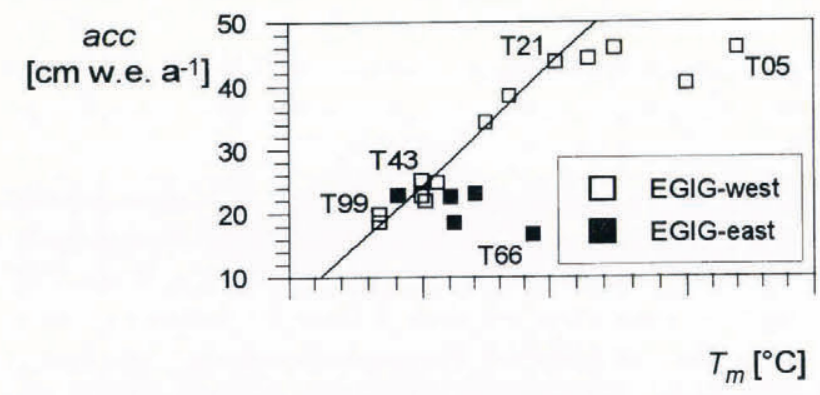

Fig. 7. Accumulation-lemperature dependence for all sites investigated along the EGIG line.

\subsection{Isotopic signature}

\subsubsection{Temporal variation of $\delta^{18} \mathrm{O}$}

Apart from the direct comparison of different temperature measurements, the temporal variation of the $\delta^{18} \mathrm{O}$ record allows identification of significant temporal trends in the atmospheric temperature on the ice sheet. The temporal distribution of the annual water-weighted mean of $\delta^{18} \mathrm{O}$ does not show any significant temporal changes along the EGIG line during the common time span covered by all firn cores. Due to the shortness of this time span (6 years), this is just an indication. Statistical testing
(Shapiro-Wilk test, $p=5 \%$ ) supports the assumption of a common unimodal normal distribution for the annual water-weighted means of each core, which cover time spans between 5 and 21 years. Thus, we conclude, provided that the advection history of the precipitationdelivering air masses, i.e. the water-vapour trajectory, remained equal, that the mean annual condensation temperature has not significantly changed during the time span covered by the firn cores.

\subsubsection{Geographical distribution of $\delta^{18} \mathrm{O}$ and $\delta D$}

$\delta^{18} \mathrm{O}$ and $\delta \mathrm{D}$, as proxy parameters for the mean annual temperature, are of special interest for the use of deep ice cores as climatic records. For such an interpretation, however, knowledge of the temperature-dependence as well as the geographical dependence of $\delta^{18} \mathrm{O}$ are crucial. Johnsen and others (1989) derived an empirical linear relationship between $\delta^{18} \mathrm{O}$ and $T_{\mathrm{m}}$ for high-altitude sites in central Greenland, which is used for the interpretation of the GRIP ice-core isotopic record

$$
\delta^{18} \mathrm{O}=0.67 T_{\mathrm{m}}-13.7(\%)
$$

An overall linear regression of the average waterweighted annual mean of $\delta^{18} \mathrm{O}$ and the $15 \mathrm{~m}$ firn temperature determined in this study leads to $\delta^{18} \mathrm{O}=$ $(0.69 \pm 0.03) T_{15 \mathrm{~m}}-(13.16 \pm 0.90) \quad \%$ \% $), r^{2}=0.97$. This is close to the relationship given by Johnsen and others (1989).

However, detailed inspection of Figure 8, showing the corresponding linear relationship for $\delta \mathrm{D}$ over the whole EGIG line, suggests the data are better fitted by two individual regression lines for the western and the eastern parts. For the deuterium data, this leads to

$$
\begin{gathered}
(\delta \mathrm{D})_{\text {west }}=(5.1 \pm 0.3) T_{15 \mathrm{~m}}-(102.0 \pm 7.4)(\%), \\
r^{2}=0.98 \\
(\delta \mathrm{D})_{\text {east }}=(4.6 \pm 0.4) T_{15 \mathrm{~m}}-(123.4 \pm 12.5)(\% \mathrm{oo}), \\
r^{2}=0.95 .
\end{gathered}
$$

The $\delta^{18} \mathrm{O}$-temperature gradients ought to be directly related to the corresponding deuterium gradients in

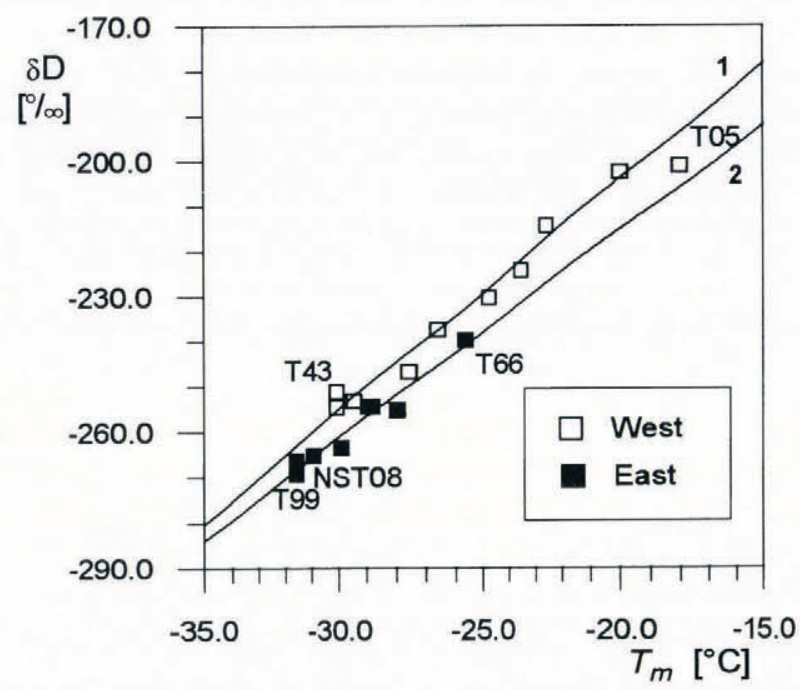

Fig. 8. $\delta D$-temperature dependence for all sites investigated along the EGIG line. 
Equations (7) and (8). Linear regression of $\delta^{18} \mathrm{O}$ and $T_{15 \mathrm{~m}}$, after correction for inter-instrumental offsets between the different spectrometers used (see also section $3.3 .3)$, leads to redundant temperature information gained by the $\delta^{18} \mathrm{O}$ and $\delta \mathrm{D}$ values

$$
\begin{aligned}
& \left(\frac{\partial \delta^{18} \mathrm{O}}{\partial T_{15 \mathrm{~m}}}\right)_{\text {west }}=(0.64 \pm 0.03) \%{ }^{\circ} \mathrm{C}^{-1}, \quad r^{2}=0.98, \\
& \left(\frac{\partial \delta^{18} \mathrm{O}}{\partial T_{15 \mathrm{~m}}}\right)_{\text {east }}=(0.60 \pm 0.04) \%{ }^{\circ} \mathrm{C}^{-1}, \quad r^{2}=0.94 .
\end{aligned}
$$

The existence of two separate regression lines for the areas east and west of the ice divide is attributed to different transport pathways of the water vapour precipitated over the Greenland ice sheet. Moist air masses from the west cause high accumulation in the western part, decreasing towards the ice divide, accompanied by a gradual depletion of the heavier isotope species during ascent (line 1 in Figure 8). When the air from the west passes the ice divide, precipitation stops. Remaining water vapour could only be further depleted in the heavier isotopes, and therefore cannot explain increasing $\delta \mathrm{D}$ values in the east. Line 2 in Figure 8 therefore must be caused by water vapour advected from the east, which is also gradually depleted in $\mathrm{D}$ and ${ }^{18} \mathrm{O}$ due to cooling during ascent. These air masses, however, are low in their water-vapour content and therefore cannot produce high accumulation rates. Again, precipitation stops when the air passes the ice divide. The higher $\delta \mathrm{D}\left(\delta^{18} \mathrm{O}\right)$-temperature gradient in the western part, is probably due to a little more isobarically influenced water-vapour trajectory over the vast ice plains of the western ice sheet, while the geographic profile shows steep slopes at the eastern ice margin, which essentially lead to adiabatic cooling of the water vapour during ascent. The westernmost site T05 deviates from line 1 in Figure 8, due to summer melting of the snow cover, causing distortion of the strata in the corresponding isotopic record. Therefore, this site was excluded from the linear regression analysis.

The assignment of the ice divide sites to one primary water-vapour trajectory (site T43 to line 1, NST08 and site T99 to line 2 ) is not straight-forward, because mixing of vapour from the west and the east can cause a breakdown of the linear relationship between $\delta \mathrm{D}\left(\delta^{18} \mathrm{O}\right)$ and $T_{\mathrm{m}}$ on the ice divide. Fisher (1992), for example, proposed mixing of vapour of both trajectories when applying a multi-source isotopic model at site T43 (Crête). However, the outcome of his model indicates that site $\mathrm{T} 43$ receives two-thirds of its water from the east, an assumption not supported by Figure 8. Most likely, the assignment of icedivide sites to one of the regimes governing the isotopic signature is dependent on local circulation conditions. The geographical distribution of $\delta^{18} \mathrm{O}$ is plotted in Figure 5 d. Here, the average $\delta^{18} \mathrm{O}$ value for site $\mathrm{T} 47$ is $\sim 1.2 \%$ lower than for site $\mathrm{T} 43$ (corresponding to $\sim 1.8^{\circ} \mathrm{C}$ by Equation (6)), while the mean annual temperature is $0.15^{\circ} \mathrm{C}$ higher. Clausen and others (1988) also found excessively depleted $\delta^{18} \mathrm{O}$ values in the Crête area east of the ice divide. This means that the geographical isotope minimum along the actual EGIG line lies alike to the accumulation minimum but contrary to the temperature minimum east of the ice divide.

\subsubsection{Deuterium excess}

Essentially independent information from $\delta^{18} \mathrm{O}$ and $\delta \mathrm{D}$ about sources and transport pathways of the water vapour precipitated over Greenland is provided by the deuterium excess $d=\delta \mathrm{D}-8 \delta^{18} \mathrm{O}$ Johnsen and others, 1989; Fisher, 1990). This parameter represents an indicator of kinetic effects occurring during the individual stages of the hydrological water cycle (i.e. evaporation at the ocean surface, and in high-polar regimes, also sublimation at snowflake formation), due to the different diffusion coefficients of $\mathrm{HDO}$ and $\mathrm{H}_{2}{ }^{18} \mathrm{O}$ vapour. Furthermore, the deuterium excess shows a distinct annual variation, essentially caused by the difference in the temperature-dependence of the equilibrium evaporation of $\mathrm{HDO}$ and $\mathrm{H}_{2}{ }^{18} \mathrm{O}$. Johnsen and others (1989) used the Rayleigh model of Jouzel and Merlivat (1984), which also considered kinetic effects during snow formation, to calculate the deuterium excess distribution along assumed water-vapour trajectories from different Atlantic Ocean source regions to central Greenland. Applying this singlesource model, the mean level of $d$ and its seasonal variation in central Greenland is mainly dependent on the evaporation temperature $T_{\mathrm{e}}$, while the slope of the $d-\delta^{18} \mathrm{O}$ curve along the trajectory and, hence, the geographical distribution of $d$ over the Greenland ice sheet, depends on the initial water-vapour mixing ratio $w_{\mathrm{e}}$ at the site of evaporation. Sensitivity studies on the model by Johnsen and others 1989 showed that the $d-\delta^{18} \mathrm{O}$ relationship is constant for an initial watervapour mixing ratio of $\sim 15 \mathrm{~g} \mathrm{~kg}^{-1}$ and that variations of $T_{\mathrm{e}}$ of $\sim 1{ }^{\circ} \mathrm{C}$ lead to an offset of the $d-\delta^{18} \mathrm{O}$ curve of $\sim 2 \%$. The outcome of all single-source models, however, is very sensitive to the tuning of the saturation history of the advected water vapour, which determines kinetic effects during snowflake formation. Therefore, Fisher (1991) proposed mixing of different saturation histories, thus varying $d$ to be responsible for the measured deuterium excess.

In Figure 5e, the geographical distribution of the average annual water-weighted mean of $d$ is plotted, showing no significant geographical trend along the EGIG line (average $d=12.7 \%$ ). Also, the annual variation of $d$ (Fig. 9b) is comparable at all sites investigated $d$ amplitude $\approx 4 \%$, phase shift relative to $\delta^{18} \mathrm{O} \approx 2$ months). Using the approach by Fisher, this would imply that the mean composition of water vapour of different saturation histories is approximately equal throughout central Greenland.

On the basis of the findings of Johnsen and others (1989), the constancy of $d$ along the whole EGIG line limits the original water-vapour mixing ratio at the site of evaporation to approximately $15 \mathrm{~g} \mathrm{~kg}$. The uniformity of the spatial and temporal distribution of $d$ also indicates the influence of possible water-vapour sources to be equal both on the western and the eastern slope of the central Greenland ice sheet. Pacific Ocean and North American source-area contributions, as stated by Charles and others (1994), which show significantly different values for $w_{\mathrm{e}}$ and $T_{\mathrm{e}}$, compared to the Atlantic Ocean, are therefore unlikely. Vapour from these sources is advected to the area investigated from west to east and therefore their influence along the eastern slope of central Greenland is presumably efficiently blocked by the ice divide. The 


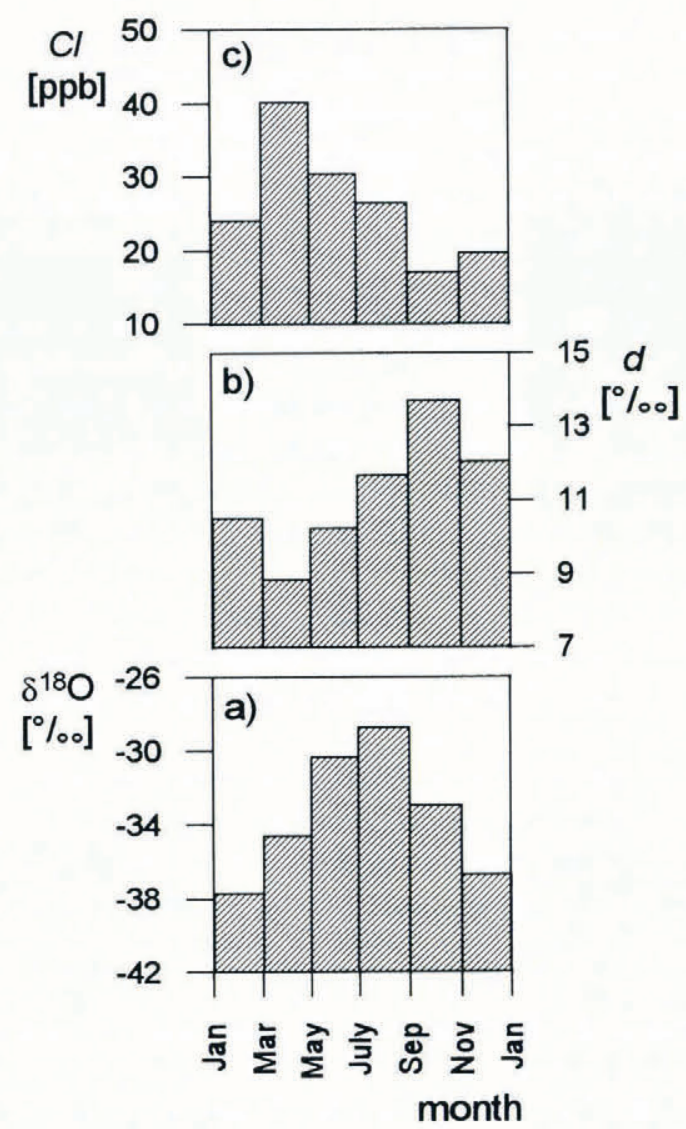

Fig. 9. Average annual variation of different isotopic and chemical parameters investigated at site $T 53$ on EGIGeast: (a) $\delta^{18} \mathrm{O}$; (b) deuterium excess $d$; (c) the waterweighted chloride concentration $\mathrm{Cl}$.

resolution of the model used by Charles and others (1994) is probably not sufficient to model the geographical distribution, since main barriers of the ice sheet and, hence, circulation on a synoptic scale cannot be taken into account appropriately.

The annual variation observed is in good agreement with the findings of Johnsen and others (1989) with respect to its amplitude and the phase shift relative to $\delta^{18} \mathrm{O}$, but our $d$ level at site T47 $(d=12.2 \pm 0.9 \%$ is significantly higher than the value of Johnsen and others at site $\mathrm{G}(d=8.9 \%$ o, which is close to site T47. The average $d$ value at site T99 (Summit) $(d=13.4 \%$ o is $\sim 3 \%$ higher than the recent values determined at GISP2 (Barlow and others, 1993). A systematic error in our study, due to the melted transport of samples from the western sites (as described in section 2.4), can be ruled out, because possible post-sampling evaporation would always lead to reduced $d$ values. Note, in this context, that the average $d$ values of the cores drilled at sites T43 and T99 in 1990 and 1992 are virtually identical. Also, a loss of fragile depth-hoar strata with lower deuterium-excess values during the drilling procedure is unlikely to be responsible for the offset, because detailed pit studies, which are not subject to loss of distinct strata, do not show significantly lower $d$ levels either. Inter-instrumental differences in our data set further show the need for quality control and intercomparison studies of the laboratories involved in isotopic ice-core analyses, to confirm the interpretation of this highly valuable hydrological tracer. So far, only very few deuterium-excess values are available for central Greenland and therefore no ultimate statement can be made. However, implications derived in this paper from the geographical distribution of the deuterium excess hold independently of the real $d$ level. Assuming our $d$ level is correct, and using the outcome of the model by Johnsen and others, the average $d$ of $12.7 \%$ would imply a $2{ }^{\circ} \mathrm{C}$ higher evaporation temperature $T_{\mathrm{e}}$, thus moving the main source area of water precipitated over central Greenland further south.

\section{SUMMARY AND CONCLUSIONS}

The temporal variations of annual snow-accumulation rates and the annual water-weighted means of $\delta^{18} \mathrm{O}$ and $\delta \mathrm{D}$ do not reveal significant trends in climatic conditions over the EGIG line for the time span covered by the firn cores. Also, comparison of the accumulation rate in the eastern part with earlier measurements indicates no significant change during the last 30 years.

The geographical distributions of the average annual accumulation rates and the mean $\delta_{18} \mathrm{O}$ content suggest a primary water-vapour trajectory along the EGIG line from west to east, resulting in a precipitation shadowing east of the ice divide. Air masses advected from the east isotopically govern the eastern slope but are not able to produce high accumulations.

This is of relevance for the interpretation of central Greenland ice cores as climatic records. So, the accumulation rate, which is thought to increase for warmer climates due to higher water-vapour content, will react differently east and west of the ice divide. While central-western sites probably show the expected increase, accumulation rates at the eastern sites probably do not react to temperature changes in a similar manner.

The isotope-climatological sub-division of the ice sheet into west and east also affects the interpretation of $\delta \mathrm{D}$ and $\delta^{18} \mathrm{O}$ as proxy temperature parameters in deep ice cores, dependent on their geographical position. A shift of the ice divide to the east, as modelled by Anandakrishnan and others (1994) for colder climates, for example, would move site T99 (recent summit) into the western area, which shows a $\delta^{18} \mathrm{O}$ offset relative to the eastern part. However, the magnitude of this effect $(\sim 1 \%$ o $)$ can only partially explain glacial-interglacial changes.

The geographical distribution and the seasonal variation of the deuterium excess are uniform over the whole EGIG line. This suggests the mean water-vapour contribution from different sources is approximately equal all over central Greenland throughout the year. Here, more detailed models have to be applied to reveal the advection and, therefore, precipitation history of the water vapour transported to Greenland.

\section{ACKNOWLEDGEMENTS}

Financial support for this study was provided by the Deutsche Forschungsgemeinschaft (DFG) and covering 
the field activities in 1990 by the Merck Stiftung and the Freundeskreis der Heidelberger Akademie der Wissenschaften. We also acknowledge the Institut für Vermessungskunde, Technische Universität Braunschweig, which was in charge of the logisitics of the traverses, the Physikalisches Institut, Universität Bern for the $\mathrm{H}_{2} \mathrm{O}_{2}$ measurements and the GSF Forschungszentrum für Umwelt und Gesundheit, Institut für Hydrologie, Neuherberg, for carrying out some of the $\delta^{18} \mathrm{O}$ and $\delta \mathrm{D}$ measurements. We should also like to thank D. A. Fisher and K. O. Münnich for very helpful comments on the draft of this paper and last, but not least, K. Geis and M. Anklin for their dedicated commitment by doing the glaciological field work during the 1990 traverse.

\section{REFERENCES}

Anandakrishnan, S., R. B. Alley and E. D. Waddington. 1994. Sensitivity of the ice-divide position in Greenland to climate change. Geophys. Res. Lett., 21(6), 441-444.

Anklin, M., B. Stauffer, K. Geis and D. Wagenbach. 1994. Pattern of annual snow accumulation along a West Greenland flow line: no significant change observed during recent decades. Tellus, 46B $(4)$, 294-303.

Barlow, L. K., J. W. C. White, R. G. Barry, J. C. Rogers and P. Grootes. 1993. The North Atlantic oscillation signature in deuterium and deuterium excess signals in the Greenland Ice Sheet Project 2 ice core, 1840-1970. Geophys. Res. Lett., 20 24), 2901-2904.

Beer, J. and 15 others. 1991. Seasonal variations in the concentrations of ${ }^{10} \mathrm{Be}, \mathrm{Cl}, \mathrm{NO}_{3}, \mathrm{SO}_{4}{ }^{2}, \mathrm{H}_{2} \mathrm{O}_{2},{ }^{210} \mathrm{~Pb},{ }^{3} \mathrm{H}$ mineral dust and $\delta^{18} \mathrm{O}$ in Greenland snow. Atmos. Environ., Ser. A, 25 (5-6), 899-904.

Boutron, C. 1979. Trace element content of Greenland snow along an east west transect. Geochim. Cosmochim. Acta, 43, 1253-1258.

Carslaw, H. S. and J. C. Jaeger, 1959. Conduction of heat in solids. Second edition. Oxford, Clarendon Press.

Charles, C. D., D. Rind, J. Jouzel, R. D. Koester and R. G. Fairbanks. 1994. Glacial interglacial changes in moisture sources for Greenland: influences on the ice core record of climate. Science, 263 (5146), 508511.

Clausen, H. B., N. S. Gundestrup, S. J. Johnsen, R. Bindschadler and J. Zwally. 1988. Glaciological investigations in the Crête area, central Greenland: a search for a new deep-drilling site. Ann. Glaciol., 10, 1015.

Dansgaard, W. 1964. Stable isotopes in precipitation. Tellus, 16 4), $436-468$.

Dansgaard, W. and 10 others. 1993. Evidence for general instability of past climate from a 250-kyr ice-core record. Nature, 364 6434), 218-220.

Davidson, C. I., J. R. Harrington, M.J. Stephenson, M.J. Small, F. P. Boscoe and R.E. Gandley. 1989. Seasonal variations in sulfate, nitrate and chloride in the Greenland ice sheet: relation to atmospheric concentrations. Atmos. Enziron, 23 (11), 2483-2493.

Finkel, R. C., C. C. Langway, Jr and H. B. Clausen. 1986. Changes in precipitation chemistry at Dye 3, Greenland. 7. Geophys. Res., 91 (D9), 9849-9855.

Fisher, D. A. 1990. A zonally-averaged stable-isotope model coupled to a regional variable-elevation stable-isotope model. Ann. Glaciol., 14, 6571.

Fisher, D. A. 1991. Remarks on the deuterium excess in precipitation in cold regions. Tellus, 43B 5 ), 401-407.

Fisher, D. A. 1992. Stable isotope simulations using a regional stable isotope model coupled to a zonally averaged global model. Cold Reg. Sci. Technol., 21(1), 61-77.

Fuhrer, K., A. Neftel, M. Anklin and V. Maggi. 1993. Continuous measurements of hydrogen peroxide, formaldehyde, calcium and ammonium concentrations along the new GRIP ice core from Summit, central Greenland. Atmos. Environ., Ser. A, 27 (12), 1873 1880.

Gundestrup, N. S. 1993. Field season report 1993. GRIP Operation Center, Glaciological Department, Geophysical Institute, University of Copenhagen, Denmark.

Haeberli, W. 1990. Glacier and permafrost signals of 20th-century warming. Ann. Glaciol., 14, 99-101.

Hansson, M. E. and E. S. Saltzman. 1993. The first Greenland ice core record of methanesulfonate and sulfate over a full glacial cycle. Geophys. Res. Lett., 20(12), 1163-1166.

Heidam, N.Z. 1981. On the origin of the Arctic aerosol: a statistical approach. Atmos. Environ., 15 8), 1421-1427.

Hempel, L. 1994. Der Zentralteil des grönländischen Inlandeises: Ergebnisse und hochauflösenden, elektromagnetischen Reflexionsmessungen. Ph.D. thesis, Westfälische Wilhelms-Universität, Münster.)

Johnsen, S.J., W. Dansgaard and J. W. C. White. 1989. The origin of Arctic precipitation under present and glacial conditions. Tellus, 41B 4 ), $452-468$.

Jouzel, J. and L. Merlivat. 1984. Deuterium and oxygen 18 in precipitation: modeling of the isotopic effect during snow formation. J. Geophys, Res., 89 (D7), 11,749-11,757.

Laternser, M. 1994. Firn temperature measurements and snow pit studies on the EGIG eastern traverse of central Greenland, 1992. Zürich, Eidgenössische Technische Hochschule. Versuchsanstalt für Wasserbau, Hydrologie und Glaziologie. (Arbeitsheft 15.)

Liljequist, H. 1970. Klimatologi. Stockholm, etc., Generalstabens Litografiska Anstalt.

Lliboutry, L. 1964-1965. Traité de glaciologie. Tome I and II. Paris, Masson.

Mayewski, P. A., M.J. Spencer, W. B. Lyons and M. S. Twickler. 1987. Seasonal and spatial trends in south Greenland snow chemistry. Almos. Environ., 21 (4), $863-869$.

Merlivat, L., J. Ravoire, J.P. Vergnaud and C. Lorius. 1973. Tritium and deuterium content of the snow in Greenland. Earth Planet. Sci. Lett., 19 (2), 235-240.

Morgan, V. I., I. D. Goodwin, D. M. Etheridge and C. W. Wookey. 1991. Evidence from Antarctic ice cores for recent increases in snow accumulation. Nature, 354 (6348), 58-60.

Ohmura, A. and N. Reeh. 1991. New precipitation and accumulation maps for Greenland. \%. Glaciol., 37 (12.5), 140-148.

Phillpot, H.R. and J.W. Zillman. 1970. The surface temperature inversion over the Antarctic continent. F. Geophys. Res., 75 (21), 41614169.

Quervain, M.de. 1969. Schneekundliche Arbeiten der Internationalen Glaziologischen Grönlandexpedition (Nivologie). Medd. Gronl., $177(4)$.

Robin, G. de Q., ed. 1983. The climatic record in polar ice sheets. Cambridge, etc., Cambridge University Press.

Seckel, H. 1977. Höhenänderungen im grönländischen Inlandeis zwischen 1959 und 1968. Medd. Grenl., 187 (4).

Sigg, A. 1990. Wasserstoffperoxidmessungen an Eisbohrkernen aus Grönland und der Antarktis und ihre atmosphärenchemische Bedeutung. (Ph.D. thesis, Universität Bern.)

Steffensen, J.P. 1988. Analysis of the seasonal variation in dust, Cl, $\mathrm{NO}_{3}$, and $\mathrm{SO}_{4}{ }^{2}$ in two central Greenland firn cores. Ann. Glaciol., 10, $171-177$. 